\title{
Front Matter: Volume 9646
}

, "Front Matter: Volume 9646," Proc. SPIE 9646, High-Performance Computing in Remote Sensing V, 964601 (20 October 2015); doi: $10.1117 / 12.2228164$

SPIE. Event: SPIE Remote Sensing, 2015, Toulouse, France 


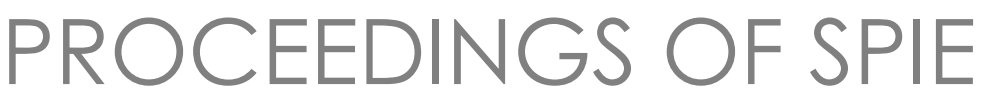

\title{
High-Performance Computing in Remote Sensing $V$
}

\author{
Bormin Huang \\ Sebastián López \\ Zhensen Wu \\ Jose M. Nascimento \\ Boris A. Alpatov \\ Jordi Portell de Mora \\ Editors
}

21-22 September 2015

Toulouse, France

Sponsored by

SPIE

Cooperating Organisations

European Association of Remote Sensing Companies (Belgium)

European Optical Society

CENSIS-Innovation Centre for Sensor \& Imaging Systems (United Kingdom)

EARSeL-European Association of Remote Sensing Laboratories

Optitec (France)

Route des Lasers (France)

Published by

SPIE

Volume 9646 
The papers in this volume were part of the technical conference cited on the cover and title page. Papers were selected and subject to review by the editors and conference program committee. Some conference presentations may not be available for publication. Additional papers and presentation recordings may be available online in the SPIE Digital Library at SPIEDigitallibrary.org.

The papers reflect the work and thoughts of the authors and are published herein as submitted. The publisher is not responsible for the validity of the information or for any outcomes resulting from reliance thereon.

Please use the following format to cite material from these proceedings:

Author(s), "Title of Paper," in High-Performance Computing in Remote Sensing $V$, edited by Bormin Huang D.D.S., Sebastián López, Zhensen Wu, Jose M. Nascimento, Boris A. Alpatov, Jordi Portell de Mora, Proceedings of SPIE Vol. 9646 (SPIE, Bellingham, WA, 2015) Six-digit Article CID Number.

ISSN: 0277-786X

ISSN: 1996-756X (electronic)

ISBN: 9781628418569

Published by

SPIE

P.O. Box 10, Bellingham, Washington 98227-0010 USA

Telephone +1 3606763290 (Pacific Time) · Fax +1 3606471445

SPIE.org

Copyright (C) 2015, Society of Photo-Optical Instrumentation Engineers.

Copying of material in this book for internal or personal use, or for the internal or personal use of specific clients, beyond the fair use provisions granted by the U.S. Copyright Law is authorized by SPIE subject to payment of copying fees. The Transactional Reporting Service base fee for this volume is $\$ 18.00$ per article (or portion thereof), which should be paid directly to the Copyright Clearance Center (CCC), 222 Rosewood Drive, Danvers, MA 01923. Payment may also be made electronically through CCC Online at copyright.com. Other copying for republication, resale, advertising or promotion, or any form of systematic or multiple reproduction of any material in this book is prohibited except with permission in writing from the publisher. The CCC fee code is 0277-786X/15/\$18.00.

Printed in the United States of America.

Publication of record for individual papers is online in the SPIE Digital Library.

\section{SPIE. DIGITAL}

Paper Numbering: Proceedings of SPIE follow an e-First publication model. A unique citation identifier (CID) number is assigned to each article at the time of publication. Utilization of CIDs allows articles to be fully citable as soon as they are published online, and connects the same identifier to all online and print versions of the publication. SPIE uses a six-digit CID article numbering system structured as follows:

- The first four digits correspond to the SPIE volume number.

- The last two digits indicate publication order within the volume using a Base 36 numbering system employing both numerals and letters. These two-number sets start with $00,01,02,03,04$, $05,06,07,08,09,0 A, 0 B \ldots$ OZ, followed by 10-1Z, 20-2Z, etc. The CID Number appears on each page of the manuscript. 


\title{
Contents
}

\author{
vii Authors \\ ix Conference Committee
}

\section{SESSION 1 HIGH PERFORMANCE COMPUTING I}

964602 The implementation of multiple objects tracking algorithm based on partition of bipartite graph in FPGA-based onboard vision systems [9646-1]

964603 Connected Component Labeling algorithm for very complex and high-resolution images on an FPGA platform [9646-3]

964604 Dimensionality reduction and endmember extraction for hyperspectral imaging using an RVC-CAL library [9646-4]

964605 Revisiting Intel Xeon Phi optimization of Thompson cloud microphysics scheme in Weather Research and Forecasting (WRF) model [9646-5]

\section{SESSION 2 HIGH PERFORMANCE COMPUTING II}

964606 GPU-based ray tracing algorithm for high-speed propagation prediction in typical indoor environments [9646-6]

964607 GPU implementation of the simplex identification via split augmented Lagrangian [9646-7]

964608 Embedded GPU implementation of anomaly detection for hyperspectral images [9646-8]

964609 RVC-CAL library for endmember and abundance estimation in hyperspectral image analysis [9646-9]

\section{SESSION 3 HIGH PERFORMANCE COMPUTING III}

9646 OB Fault-tolerant NAND-flash memory module for next-generation scientific instruments [9646-11]

9646 OC APES-based procedure for super-resolution SAR imagery with GPU parallel computing [9646-12]

9646 OD FAPEC-based lossless and lossy hyperspectral data compression [9646-13]

9646 OF Application of Intel Many Integrated Core (MIC) accelerators to the Pleim-Xiu land surface scheme [9646-15] 
9646 OG GPU-based ray tracing algorithm for high-speed propagation prediction in multiroom indoor environments [9646-16]

$9646 \mathrm{OH} \quad$ Performance tuning Weather Research and Forecasting (WRF) Goddard longwave radiative transfer scheme on Intel Xeon Phi [9646-17]

9646 Ol A novel hardware-friendly algorithm for hyperspectral linear unmixing [9646-18]

9646 0J Parallel implementation of the multiple endmember spectral mixture analysis algorithm for hyperspectral unmixing [9646-20]

\section{SESSION 5 HIGH PERFORMANCE COMPUTING V}

$96460 \mathrm{M}$ Performance portability study of an automatic target detection and classification algorithm for hyperspectral image analysis using OpenCL [9646-24]

$96460 \mathrm{~N} \quad$ Accelerating the prediction-based lower triangular transform for data compression using Intel MIC [9646-25]

\section{SESSION 6 HIGH PERFORMANCE COMPUTING VI}

964600 Optimizing the Betts-Miller-Janjic cumulus parameterization with Intel Many Integrated Core (MIC) architecture [9646-26]

9646 OP Parallel hyperspectral compressive sensing method on GPU [9646-27]

9646 OR GPU-based parallel clustered differential pulse code modulation [9646-29]

\section{SESSION 7 HIGH PERFORMANCE COMPUTING VII}

9646 OT Differential evolution algorithm-based kernel parameter selection for Fukunaga-Koontz Transform subspaces construction [9646-31]

$96460 \mathrm{~A} \quad$ Accelerated ray tracing algorithm under urban macro cell [9646-32]

\section{POSTER SESSION}

9646 OW The scale effects of anisotropic land surface reflectance: an analysis with Landsat and MODIS imagery [9646-19]

9646 0X Semi-supervised classification tool for DubaiSat-2 multispectral imagery [9646-22]

9646 OY Parallel algorithm of real-time infrared image restoration based on total variation theory [9646-34] 
964610 Fault tolerance of SVM algorithm for hyperspectral image [9646-36]

964611 A lossless compression algorithm for aurora spectral data using online regression prediction [9646-37]

Proc. of SPIE Vol. $9646964601-5$

Downloaded From: https://www.spiedigitallibrary.org/conference-proceedings-of-spie on 26 Apr 2023 Terms of Use: https://www.spiedigitallibrary.org/terms-of-use 
Proc. of SPIE Vol. $9646964601-6$

Downloaded From: https://www.spiedigitallibrary.org/conference-proceedings-of-spie on 26 Apr 2023 Terms of Use: https://www.spiedigitallibrary.org/terms-of-use 


\section{Authors}

Numbers in the index correspond to the last two digits of the six-digit citation identifier (CID) article numbering system used in Proceedings of SPIE. The first four digits reflect the volume number. Base 36 numbering is employed for the last two digits and indicates the order of articles within the volume. Numbers start with 00, 01, 02, 03, 04, 05, 06, 07, 08, 09, 0A, 0B...0Z, followed by 10-1Z, 20-2Z, etc.

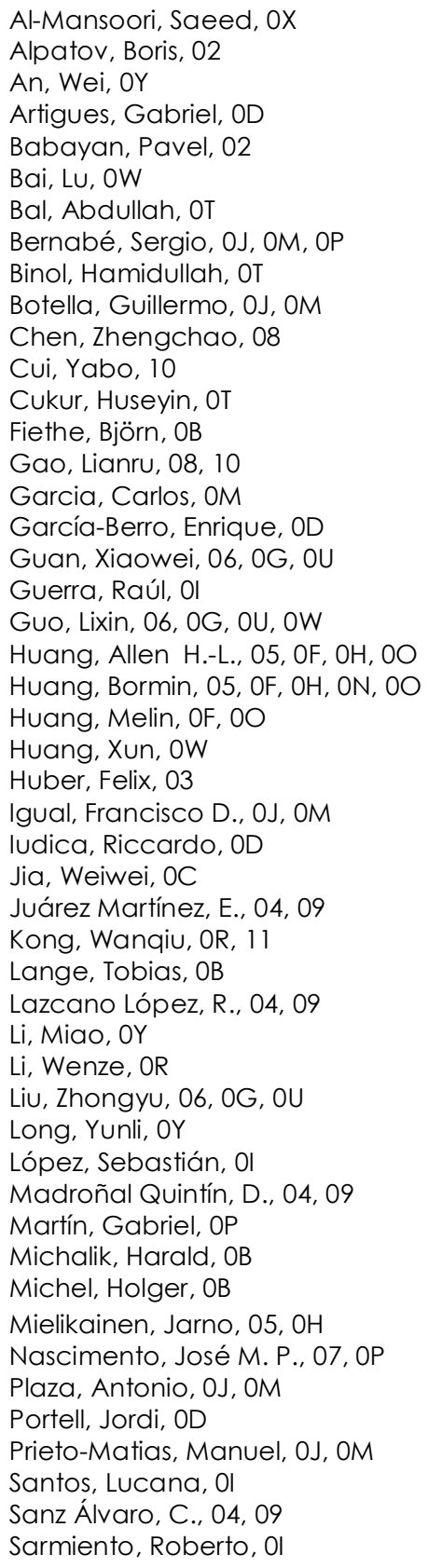

Schwenk, Kurt, 03

Sevilla, Jorge, 07

Strotov, Valeriy, 02

Walter, Dietmar, OB

Wei, Shih-Chieh, ON

Wu, Jiaji, OR, 11

Wu, Yuanfeng, 08, 10

Wu, Zhensen, OW

XU, Guangyao, OC

$\mathrm{Xu}$, Xiaojian, $\mathrm{OC}$

Yang, Bin, 08

Yuan, Zhengwu, 10

Zeng, Yaoyuan, OY

Zhang, Bing, 08

Zhang, HaO, 10

Zhu, Ran, OY 
Proc. of SPIE Vol. $9646964601-8$

Downloaded From: https://www.spiedigitallibrary.org/conference-proceedings-of-spie on 26 Apr 2023 Terms of Use: https://www.spiedigitallibrary.org/terms-of-use 


\section{Conference Committee}

Symposium Chair

Charles R. Bostater, Florida Institute of Technology, Marine-

Environmental Optics Laboratory and Remote Sensing Center

(United States)

Symposium Co-chair

Klaus Schäfer, Karlsruher Institut für Technologie, Institute of Meteorology and Climate Research (Germany)

Conference Chairs

Bormin Huang D.D.S., University of Wisconsin-Madison (United States)

Sebastián López, Universidad de Las Palmas de Gran Canaria (Spain)

Zhensen Wu, Xidian University (China)

Conference Co-chairs

Jose M. Nascimento, Instituto de Telecomunicações (Portugal)

Boris A. Alpatov, Ryazan State Radio Engineering University

(Russian Federation)

Jordi Portell de Mora, Universidad de Barcelona (Spain)

Conference Program Committee

Saeed H. Al-Mansoori, Emirates Institution for Advanced Science and Technology (United Arab Emirates)

Chein-I Chang, University of Maryland, Baltimore County

(United States)

Yang-Lang Chang, National Taipei University of Technology (Taiwan)

Mingmin Chi, Fudan University (China)

Qian Du, Mississippi State University (United States)

Dustin Feld, Universität zu Köln (Germany)

Carlos E. Garcia Gonzalez, Universidad Complutense de Madrid (Spain)

Lixin Guo, Xidian University (China)

Eduardo Juarez, Universidad Politécnica de Madrid (Spain)

Tsengdar J. Lee, NASA Headquarters (United States)

Francesco Leporati, University degli Studi di Pavia (Italy)

Qiguang Miao, Xidian University (China)

Caner Özcan, Karabük Üniversity (Turkey)

Enrique S. Quintana-Orti, Universidad Jaume I (Spain) 
Prashanth Reddy Marpu, Masdar Institute of Science \& Technology (United Arab Emirates)

Jarno Mielikainen, University of Wisconsin-Madison (United States)

Antonio J. Plaza, Universidad de Extremadura (Spain)

Jeffery J. Puschell, Raytheon Space \& Airborne Systems

(United States)

Shen-En Qian, Canadian Space Agency (Canada)

Sergio Sanchez Martinez, Masdar Institute of Science \& Technology (United Arab Emirates)

Roberto Sarmiento, University de Las Palmas de Gran Canaria (Spain)

Valeriy V. Strotov, Ryazan State Radio Engineering University (Russian Federation)

Yuliya Tarabalka, INRIA Sophia Antipolis - Méditerranée (France)

Carole Thiebaut, Center National d'Études Spatiales (France)

Tanya Vladimirova, University of Surrey (United Kingdom)

Shih-Chieh Wei, Tamkang University (Taiwan)

Jiaji Wu, Xidian University (China)

Session Chairs

1 High Performance Computing I

Bormin Huang, University of Wisconsin-Madison (United States)

2 High Performance Computing II

Sebastián López, Universidad de Las Palmas de Gran Canaria (Spain)

3 High Performance Computing III

Zhensen Wu, Xidian University (China)

4 High Performance Computing IV

Jose M. Nascimento, Instituto de Telecomunicações (Portugal)

5 High Performance Computing $\mathrm{V}$

Jordi Portell de Mora, Universidad de Barcelona (Spain)

6 High Performance Computing VI

Jarno Mielikainen, University of Wisconsin-Madison (United States)

7 High Performance Computing VII

Valeriy V. Strotov, Ryazan State Radio Engineering University

(Russian Federation) 